\title{
Børn i det kreative samfund
}

\author{
Af Eva Harpøth Johannesen
}

Informationssamfund. Videnssamfund. Netværkssamfund. Fremtiden har mange navne. I Next Generation Forum har vi taget endnu et skridt i retning af at få styr på hvad fremtiden handler om, og er nået til den konklusion, at fremtidens samfund må være et kreativt samfund.

Information, viden og netværk har alle det til fælles, at de er uden værdi, hvis de ikke bruges af mennesker. Succes i fremtidens verden vil således ikke være baseret på information, heller ikke på viden eller netværk, men på at viden anvendes kreativt. Derfor bliver kreativitet den mest centrale ressource. Derfor det kreative samfund.

Børn er vitale $i$ overgangen til et kreativt samfund, ikke blot fordi de udgør "næste generation", men også fordi barndommen naturligt er en af de mest kreative perioder i vores liv. På mange måder kan børn tjene som modeller for livet i det kreative samfund, og hjælpe resten af samfundet med at lære, hvad det betyder at lege og være kreativ. Dette bliver i stigende grad relevant, efterhånden som fantasi og fleksibilitet bliver nøgleværdier på arbejdsmarkedet og i det enkelte menneskes hverdag.

\section{Hvad er Next Generation Forum?}

Next Generation Forum er et uafhængigt netværk af eksperter, viden og best practices inden for feltet kreativitet og læring. Next Generation Forum består af fire elementer:

The Next Generation Roundtable - som består af 8-10 internationale eksperter inden for børn og kreativitet.

The Next Generation Annual Report - som hvert efterår rapporterer om årets arbejde og resultater.

The Next Generation Summit - som skal samle hovedaktører i børns liv i en diskussion af vejen til det kreative samfund.

The Next Generation Map of Creativity som skal udvikles til verdens største on-line ressource, der kan inspirere andre til at børns kreative potentiale forløses.

Next Generation Forums aktiviteter er finansieret af LEGO Company, mens Mandag Morgen Strategisk Forum fungerer som analyseenhed. 


\section{Det kreative samfunds geografi}

Et kort over det kreative samfund ville vise en verden som betragter børn som sin vigtigste inspiration og investering. En verden, som arbejder på at videreføre barndommens kvaliteter til voksenlivet.

Barndommen er nemlig bl.a. karakteriseret ved, at det er her, mennesket er i bedst kontakt med sin nysgerrighed, sit videbegær, sin naturlige trang til at udforske verden og forstå den. Alle centrale elementer i det at være kreativ.

Kreativitet bliver ofte knyttet til et kunstnerisk udtryk. Men det er en misforståelse. Som den svenske professor i børnepsykologi, Ingrid Pramling Samuelsson, siger, så

"er det for snævert at se kreativitet som noget, der kun har at gøre med at male og lave teater osv. Kreativitet er en del af videnskaben og en del af af det at lære".(1)

Det kreative samfund, er et samfund, som i sit væsen og sine værdier adskiller sig fra det industrielle samfund. Se figur i næste spalte.

Det kreative samfund er det samlede produkt af de forandringer vi ser omkring os. De fleste af disse kan samles i fire globale tendenser:

- Den nye $\phi k$ konomis gennembrud

- De nye teknologier giver nye muligheder

- Stærkt fokus på livslang læring

- Individualisering og nye former for fællesskab

Den nye фkonomis gennembrud bliver stadigt tydeligere. I løbet af de sidste få tiår har strukturen i $\emptyset$ konomien, erhvervslivet og arbejdsmarkedet ændret sig dramatisk i mange dele af verden. $\varnothing$ konomien er blevet global, og verdenshandlen består ikke længere primært af industriprodukter, men af handel i finansielle ydelser og andre serviceprodukter. Den del af verdenshandlen er i dag 50 gange mere værd end handelen med fysiske produkter. Det er derfor, den nye $\varnothing$ konomi af nogen har fået tilnavnet den "vægtløse" $\emptyset$ konomi. Den nye $\emptyset$ konomi bygger i høj grad på ikke-fysiske ressourcer såsom viden, information, mærke-

\section{Det kreative samfunds principper}

Seks skift tegner vejen mod det kreative samfund Fra.. Til..

...fokus pá institutioner og systemer



fokus på menneskelige ressourcer og væerdier.

.nationers

konkurrenceevne

fokus pa færdigheder og fakta

..voksen som eneste idé-kilde

..industriprodukter baseret på fysiske ressourcer

..teknologi bruges til at gøre det samme hurtigere



..fokus pa kreativitet, legesyge og laring



.fokus pá born som

.produkter baseret pá ideer, kreativitet og andre menneskelige ressourcer

.teknologi bruges til at gore helt nye ting vardifuld idé-kilde

NGF Sekretariatet, 2000

varer, goodwill, forskning \& udvikling og netværk. En amerikansk undersøgelse af mere end 2000 amerikanske virksomheder nåede frem til, at kun en tredjedel af virksomhedernes markedsværdi kunne tilskrives deres fysiske aktiver såsom bygninger, maskiner, produktionsudstyr osv. Stort set alle produkter er tillige begyndt at opføre sig som software, hvor en vares værdi ligger i informationen frem for i selve tingen. F.eks. er kun 16 pct. af en bils værdi forankret i materialer. Resten ligger $i$ design, markedsf $\varnothing$ ring, distribution og andre uhåndgribelige aktiver. (2).

Det laver grundlæggende om på virksomhedernes konkurrenceunivers. Fordelene ligger ikke længere $\mathbf{i}$ en stabil produktionsproces eller $\mathbf{i}$ at kunne levere en ensartet kvalitet hver gang. Ikke at det bliver ligegyldigt - det er bare ikke noget, man kan høste fordele ved at kunne, men en basal forudsætning for overhovedet at kunne være med i spillet. Det er virksomhedernes evne til at skabe "vægtløse" værdier og udvikle ideer, der bliver afgørende for succes.

Indtil nu har begrebet den nye økonomi i høj grad været knyttet til IT-branchen med dens fantastiske eventyr på aktiemarkedet fyldt af tempo og 
drama. Men det handler om langt mere end det. Det handler om et kulturelt skift, som vil ramme alle dele af $\emptyset$ konomien. Det handler om en ny arbejds- og virksomhedskultur, hvor mennesker og deres potentiale er i centrum. Især teknologien baner vej for dette frirum for mennesker.

De nye teknologier giver nye muligheder i en verden, hvor alle er elektronisk forbundet med alle andre. Hvor både mennesker og ting kommunikerer utvungent på trods af geografisk afstand, forskelle i kultur, alder, køn, race osv.

Et centralt aspekt ved den nye teknologi er, at den giver helt nye muligheder for at forstå abstrakte eller blot komplicerede fænomener, som det har været ekstremt svært at forklare med de redskaber, som før har været til rådighed.

I en verden, der bestod af en-vejskommunikation - som f.eks. tv, eller to-dimensionelle redskaber som papir og blyant, eller stationære redskaber som klodser osv., kræver det et højt abstraktionsniveau at forklare, hvorfor fugle flyver i flok, hvordan man konstruerer en cirkel osv. Uanset hvilket redskab man vælger, kan de ikke, som moderne teknologi, på én gang inddrage brugeren og vise mange dimensioner og bevægelser (3). Nye vidensområder bliver med teknologien tilgængelige for os alle, og for børn især langt tidligere end det var muligt $f \varnothing r$.

Et andet nøglefænomen ved den teknologiske udvikling er, at den frigør menneskers tid. Det er blevet muligt at automatisere meget produktion og rutineprocesser i almindelighed, og dermed får man ganske enkelt hjernekapacitet i overskud. På nuværende tidspunkt er store dele af den overskudskapacitet gået i gang med at udvikle nye måder at bruge de nye teknologier på, i form af enten forretningskoncepter, undervisningsmaterialer, sammensmeltede medier og meget andet. Med andre ord at kombinere viden på nye måder - at være kreative.

Livslang laring er kommet stærkt i fokus i de senere år. Regeringer verden over taler om det og udvikler politiske initiativer, der skal få arbejdsstyrken til at blive ved med at lære nyt hele livet. For i en verden hvor det at finde på noget nyt er afgørende, må langt flere blive ved med at tilegne sig ny viden og nye kompetencer.

Uddannelse per se er ikke nødvendigvis svaret. Det afhænger aldeles af indholdet. Kardinalpunktet er at finde måder, hvor det at lære noget nyt, bliver ved med at være sjovt. Det handler om at kunne antænde nysgerrighed og energi i den enkelte, så man konstant søger udover grænserne i ens egen viden. Så man udforsker nye områder. Dette er essensen af livslang læring - at evnen til at forblive motiveret for læring efter obligatoriske uddannelsesforløb er langt vigtigere, end den faktuelle viden som den traditionelle skole vil prise.

På den måde kommer viden til at dreje sig mindre om fakta, og mere om hvordan man kan forstå, og skabe mening i og af den verden, man lever i. Og det kan der være god grund til.

Individualisering og nye former for follesskab er sidste tendens, der peger i retning af forandring. Gennem det sidste tiår er det blevet fremhævet, at individualisme og individualisering påvirker de fleste kulturer i verden. Men det er en individualisme, som er væsensforskellig fra tidligere. Spørgsmålstegn bliver stillet ved den traditionelle opfattelse af individ vs. fællesskab. I stadig større grad bliver udviklingen af den enkeltes unikke potentiale set - ikke som en trussel mod sammenhængskraften i samfundet - men som en forudsætning for at opretholde nogen form for sammenhæng og udvikling.

Det nye fokus på individet er knyttet til globaliseringen. Faste holdepunkter som religion, videnskab, offentlige myndigheder og familien er under pres (4). Der sker en slags kulturel frisættelse. Den enkelte kan vælge og fravælge informationer, tilhørsforhold, livsstil, formål og endda national identitet. Livet består i dag af langt flere valg for den enkelte. Vi skal alle aktivt konstruere vores eget liv, vore egne værdier og dermed vore egne fællesskaber. Det kræver stor bevidsthed om og tro på egne kompetencer. $\mathrm{Og}$ det gælder særligt den næste generation.

Det er nutidens (og fremtidens) børn, som især skal være klar til at foretage de individuelle valg, 
men stadig med respekt for det fællesskab de lever i. De skal være klar til at navigere deres eget liv, samtidig med at de knytter sig til den kulturelle og sociale kontekst, de indgår i. De skal være klar til at skabe deres egne liv langt mere aktivt end før og stå til ansvar for konsekvenserne af deres valg.

På den ene side må børn have plads til at udvikle alle deres individuelle kompetencer, men sideløbende udvikle en vilje til at bruge deres individuelle potentiale også til fællesskabets bedste.

Alle disse tendenser fører til, at menneskelige ressourcer er den primære kilde til produktivitet og konkurrenceevne. Innovation og nytænkning er kernen til overlevelse i den nye фkonomi, og kreativitet kommer naturligt frem i forreste række når arbejdsgivere skal pege på vigtige kompetencer hos fremtidens medarbejdere.

\section{Fremtidens kompetencekrav}

Tendenserne ovenfor tegner konturerne af den verden, den næste generation skal leve og vokse i. Det er det kreative samfund, som har mennesker og deres kompetencer som vigtigste ressource.

Den tydeligste arena for dette er i dag virksomhederne, som kappes om at tiltrække og fastholde de bedste medarbejdere. Men kompetencer er ikke bare et spørgsmål om virksomhedernes konkurrenceevne. Det er også en væsentlig dannelsesdimension, som handler om at give det enkelte menneske muligheder for at udfolde sit potentiale hele livet, så han eller hun på den måde til stadighed kan sikre sig en plads i samfundet.

Men hvilke kompetencer? Kompetencebegrebet har i løbet af de seneste år både vundet udbredelse og er kommet under debat. Danmarks første nationale kompetenceregnskab kom i slutningen af 1999. Den alternative vismandsinstitution Kompetencerådet, som er etableret af Huset Mandag Morgen, arbejdede i denne rapport med fire overordnede kompetencer (5). Det er det danske samfunds evne til at udvikle og underst $\varnothing$ tte disse fire brede kompetencer, som regnskabet gør op. Samtidig er det de fire kompetencer, som bliver afgørende for det enkelte menneske at beherske:
Laringskompetence - adgangen til viden er ikke længere afgørende, men derimod evnen til at tilegne sig viden og omforme den til værdiskabende handling. Det kræver faglige kundskaber, læring gennem hele livet og læring på tværs af kulturer.

Forandringskompetence - fremtiden fordrer vilje til at flytte sig, mentalt, fysisk og rollemæssigt, og en evne til at sætte i værk. Kompetencen udtrykker sig i innovationsevne, mobilitet og selvstændighed.

Relationskomptence - evnen til at skabe relationer og netværk, evnen til at håndtere forskellighed bliver vigtigt. Kulturel rummelighed og relationer bliver forudsætninger for at kunne begå sig i et stadigt mere fragmenteret samfund. Det kræver udvikling af social intelligens gennem leg, samvær og samarbejde. Det drejer sig om at kunne skabe netværk, at kunne kommunikere og at tage ansvar for sin egen læring og udvikling.

Meningskompetence - kravene til individuelt og kollektivt at kunne se, skabe og dele mening er stadigt større. At kunne det, kræver en klar fornemmelse af egen identitet og eget fokus. Kompetencen udtrykkes gennem evnen til at identificere og fokusere på sine kernekompetencer, at opnå resultater og at kunne skabe og formidle sin egen identitet. Uden meningskompetence bliver det umuligt at finde ståsted eller retning i fremtidens samfund.

Det er det kompetenceunivers næste generation skal navigere i. Og når vi nu er ved dem - hvem er de så, den næste generation?

\section{Børn er foran}

Alle generationer adskiller sig fra den, der kom før. Generationer formes af de strømninger, redskaber og begivenheder, som foregår, sideløbende med at børn i en generation vokser op. Udviklingens hastighed kommer på den måde til at afgøre, hvor stor afstanden mellem én generation og den næste er.

Det interessante er, at for det barn, der lever midt i strømningerne, begivenhederne og de nye redskaber, er intet af det, der sker, nyt og særligt. Nuti- 
den er børns real-tid, som de ikke oplever gennem briller og forventninger formet af tiden før.

$\operatorname{Pr} \varnothing v$ at tænke tilbage til din egen barndom. Hvad var den største teknologiske opfindelse på det tidspunkt. For én generation var det fjernsynet. Oplevede du nogensinde fjernsynet som noget fremmed? Som en unaturlig del af din verden? Undrede du dig nogensinde over, hvordan du kunne se indslag fra andre lande? Var det svært for dig at lære at skifte programmer?

Svaret til de fleste af de spørgsmål er for forældregenerationen i dag "nej". Og det er den situation nutidens børn står i med deres generations største teknologiske gennembrud - digital kommunikation.

B $\varnothing$ rn og unges holdning til ny teknologi i almindelighed og dens brug af internettet i særdeleshed, er nok det mest markante kendetegn ved den næste generation. Nutidens unge er vokset op med computeren og Internettet både hjemme og i skolen, og de bruger dette værkt $\varnothing \mathbf{j}$ langt mere - og ofte langt dygtigere - end deres forældre.

Man taler om at børn og unge i dag ikke bare er brugere af computere og Internet, men at de har internaliseret det. Hvor voksne tilføjer viden om ny teknologi til deres allerede eksisterende verdenssyn, så er computere, Internet, mobiltelefoner osv. allerede en del af børnenes referenceramme.

Børn er i det hele taget bedre rustet til at indgå i det kreative samfund, end langt de fleste voksne $\mathbf{i}$ dag. Overordnet set kan man tale om, at det kreative samfunds nøglebegreber er indlejret i barndommen og de karakteristika, man tillægger den livsfase. Det kreative samfunds nøglebegreber er illustreret $\mathrm{i}$ figuren overfor.

Barndommen karakteriseres netop af legen, af det udforskende, af at lære på alle måder og alle steder. Er der noget børn er gode til, er det til gennem leg at udfordre sig selv og sine evner, fors $\emptyset$ ge at skabe mening i og forstå deres verden, dvs. lære.

Når børnene er foran på en række af de områder, der defineres som afgørende i fremtiden, opstår
Det kreative samfunds noglebegreber

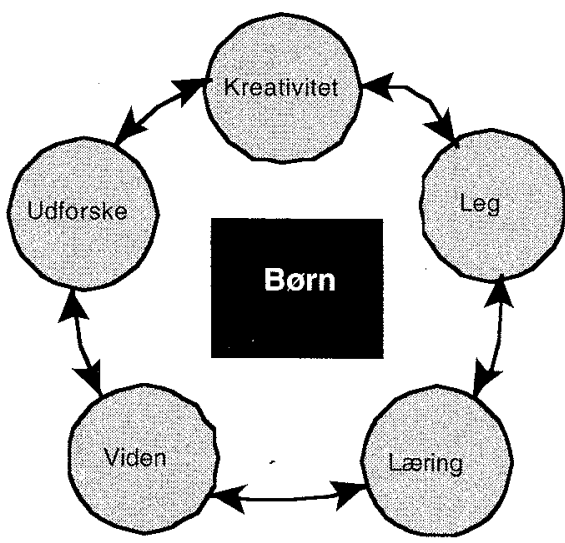

Next Generation Forum 1999

en rakke situationer, hvor autoritetsforholdet mellem børn og voksne vender og står på hovedet. Der er efterhånden en del historier om børn som rollemodeller for voksne.

Et eksempel stammer fra Butler University i Indiana, USA, hvor "junior professorer" bliver koblet med lærerstuderende. Junior-professorerne kommer fra første til femte klasse, og lærer de kommende lærere hvordan grafik- og hypermediaprogrammer virker. Målet har været at gøre op med forestillingen om, at teknologi er for svært for mindre børn, men også at bruge så mange metoder som muligt til at forstå, hvordan teknologi kan bruges i undervisningen. Og det slår aldrig fejl: De voksne bliver overraskede over både børnenes færdigheder og tilgang til teknologien, som på begge områder er på et højere niveau end de voksnes.

\section{Puslingepower: Børn som forbrugermagt}

Nutidens børn kan kendes på en anden front: De får en mere og mere central placering i den kommercielle del af samfundet. Både virksomheder og forældre er ved at få øjnene op for, at den yngste befolkningsgruppe rummer et stort forbrugspotentiale. 
Dels får børn selv flere penge mellem hænderné. Dels påvirker de forældrenes forbrug som aldrig før. Og dels bliver børn meget tidligt mærkevarebevidste og loyaliteten kan derfor grundlægges tidligt.

Siden 1960'erne er amerikanske børns samlede købekraft fordoblet cirka hvert tiende år. I 1990 'erne alene er den tredoblet. Børn og unge mellem 5 og 20 år brugte i 1998 omkring 980 milliarder kroner - kun på eget forbrug. Heraf brugte børn mellem 4 og 12 år næsten 181 milliarder af deres egne penge. (6).

Dertil kommer børns indflydelse på den samlede families forbrug. Unders øgelser fra både USA og England viser, at barnet ofte bestemmer familiens feriedestination, computeren, og sågar hvilken bil familien skal have. En britisk undersøgelse fra 1997 viste, at 12-årige spiller en afgørende rolle i familiens valg af 31 pct. af alle feriedestinationer, 30. pct. af alle bilmodeller og 22 pct. af alle stereoanlæg. Børn mellem 4 og 12 havde i USA i 1998 direkte indflydelse på 1.358 milliarder kroner af deres forældres forbrug, og indirekte indflydelse på yderligere 2.166 milliarder kroner. (7).

Karakteren af børns forbrug har også ændret sig væsentligt i løbet af de seneste år. Børn overgår tidligere til et mere voksent forbrugsmønster end nogensinde før. F.eks. har den amerikanske brancheforening for legetøjsproducenter ændret sin primære demografiske målgruppe fra at være de 0-14-årige til at være de 0-10-årige. Ændringerne i børns forbrug skyldes til dels, at det nu er blevet muligt for børn at anskaffe sig normale funktionelle produkter. Priserne på f.eks. transportable CD-afspillere, mobiltelefoner, mountain bikes, fjernsyn osv. er faldet så meget, at de ofte ikke er dyrere - og i nogle tilfælde endda er billigere -end meget leget $\varnothing \mathrm{j}$.

Sidst, men ikke mindst, er børn fremtidens forbrugere. Derfor ofrer f.eks. en stor bilkoncern gerne store summer på at reklamere for deres voksentegneserier i Anders And-bladet.

På den ene side er udviklingen i produkter og reklamer, der er målrettet børn, både bekymrende og i visse tilfælde grænsende til uetisk, fordi børn ikke har samme filter over for reklamer og deres påvirkningsmidler som de fleste voksne. På den anden side vil stigningen $i$ børns forbrug og betydning medføre, at børnene direkte og indirekte får større indflydelse på deres omgivelser. Kriteriet for at børn ikke drukner i forbrugsstrømmen er, at de gennem deres udvikling rustes med kompetencer, der $\mathrm{g} \emptyset \mathrm{r}$ dem i stand til at forholde sig kritisk til omverdenens budskab, og derigennem bliver ikke bare kompetente mennesker og borgere, men også komptente forbrugere.

\section{Nyt børnesyn giver bedre plads}

Børn som kompetente forbrugere og børn som rollemodeller for voksne ville for få år siden have været ganske utænkeligt. Men børnesynet har i løbet af de seneste årtier ændret sig i takt med samfundet. Sideløbende med samfundsudviklingen har ny viden fra forskningens verden, givet os en ny måde at forstå børn på, som giver barnet langt mere plads til at deltage på egne vilkår. Den danske forsker i børnspsykologi Dion Sommer har en rammende beskrivelse af det gamle børnesyn:

"Det var fuldstændig nonsenssnak. Man opfattede barnet som uden sociale evner, uden kom-

\section{Nyt samfund - nyt børnesyn}

\begin{tabular}{|c|c|}
\hline Industrisamfund & Kreativt samfund \\
\hline Viden er universet & $\begin{array}{l}\text { Viden knyttet til kultur } \\
\text { og historie }\end{array}$ \\
\hline $\begin{array}{l}\text { Familien som } \\
\text { eneste base }\end{array}$ & $\begin{array}{l}\text { Et netvark af menne- } \\
\text { skelige forbindelser }\end{array}$ \\
\hline Moderen l centrum & $\begin{array}{l}\text { Borns multipersonelle } \\
\text { forbindelser }\end{array}$ \\
\hline Det skrobelige barn & Det kompetente barn \\
\hline Udvikling i trin & Udvikling af mange \\
\hline Socialisering & Barnet som aktør \\
\hline $\begin{array}{l}\text { Stimulering og } \\
\text { undervisning }\end{array}$ & $\begin{array}{l}\text { Vidensøgning og aktiv } \\
\text { læring }\end{array}$ \\
\hline
\end{tabular}

Next Generation Forum 1999, baseret på Dion Sommer, 1996 
petencer. Alt skulle puttes ind i barnet af de voksne omkring det, barnet var som en klump ler, der passivt blev formet af de voksne omkring det". (8).

Dette børnesyn er bestemt ikke fremherskende længere. Det moderne børnesyn er sammenfattet i figuren nedenfor. Den nye viden, der ligger til grund for store dele af det ændrede børnesyn kommer - i store træk - fra tre forskningsfelter (9):

- Pcedagogisk/psykologisk forskning har i stigende grad formidlet, at børn fødes motiverede for at lære, samt at de har langt flere kompetencer, end man traditionelt har troet. Samtidig er der opnået en stadigt mere uddybet forståelse af, at menneskets mulighed for at lære hænger tæt sammen med dets evne til at forme en identitet. Populært sagt skal man lære at være for at kunne lære at lære.

- Hjerneforskningen har kortlagt flere af hjernens funktioner og muligheder i løbet af de seneste tiår, og har fundet, at hjernen kan blive ved med at udvikle sig og lære nye ting. Det er med stadigt mere avancerede redskaber muligt at se, hvornår de netværk, der bestemmer hjernens funktion er aktive - og dermed muligt at få bedre kendskab til de omstændigheder, som lukker hjernen op for udvikling.

- Intelligensforskning har søgt ud over den traditionelle intelligensdefinition, der benyttes i IKtests og har udvidet intelligensbegrebet til en række forskellige slags intelligenser. F.eks. opererer Harvard-forskeren Howard Gardner med mindst syv forskellige intelligenser, der hver for sig kan udvikles. En anden forsker, Daniel Goleman, har arbejdet med at definere den følelsesmæssige intelligens, som handler om at se på menneskets evne til at indgå i sociale relationer.

\section{Børns kreative potentiale skal forløses}

I en verden hvor menneskers evne til kreativt og i fællesskab at udvikle og bruge deres kompetencer er afgørende, bliver forløsningen af børns kreative potentiale højeste prioritet.
Alle mennesker er i udgangspunktet søgende, nysgerrige og opfindsomme. Kreative. Og en af de største udfordringer i de kommende år er i alle samfundets hjørner at skabe de bedste muligheder for at udvikle menneskets iboende kreativitet. Det stiller krav om en dybfølt forpligtelse til ikke at lade barndommen og børns verden overskygge af $\emptyset$ nsket om at forme børn til en traditionel voksenverden.

Projektet Next Generation Forums væsentligste mission er da også at sætte fokus på børns udvikling og læring gennem kreativitet og leg. Ikke primært for at sikre at arbejdsmarkedet fremover vil være forsynet med en arbejdsstyrke tilpasset i den rigtige retning. Nej, primært for at sikre at nutidens børn sikres de bedste forudsætninger for at kunne indgå fuldt og helt $\mathrm{i}$ fremtidens samfund det kreative samfund.

Det kræver, at vi i dag arbejder på at finde de bedst mulige måder at udvikle børns potentiale. Next Generation Forum har defineret fem grundlæggende værdier og retningslinier for, hvordan

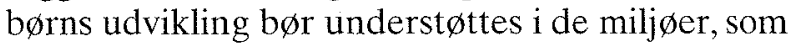
børnene kommer i:

- Børn skal opfordres til at teste grænserne i deres eget univers.

- Børn skal gives mulighed for at designe og skabe deres egne læringsprocesser.

- Børn skal støttes i deres vej mod viden, så de făr en dybere forståelse af den verden de lever $i$, og hvordan de selv indgår i den.

- Børn skal have det rette mix af frihed og struktur for at udvikle sig. Det skal ske i et miljø, der opfordrer til en legende tilgang med variation i udtryks- og læringsformer. Der skal være klare forbindelser til det omgivende samfund.

- Formelle og uformelle kompetencer har lige stor vægt $i$ et nyt læringsbegreb, der kombinerer følelsesmæssige, sociale og kognitive kompetencer.

Next Generation Forum lægger desuden vægt på at forståelsen af, hvor børn lærer og udvikler sig 
udvides kraftigt. Selvom børns læring reelt sker i alle de arenaer børn indgår $i$, ses skolen som det eneste egentlige læringsmiljø. På grund af dette monopol er interaktion og integration af de forskellige børnemiljøer - daginstitutioner, skoler, fritidsordninger, klubber, kulturprojekter, biblioteker, legepladser, gader, skove - ofte lav. Og det er børns udvikling, der taber.

Allerede i dag findes der en række projekter, der lever op til disse idealer. Det måske bedste af dem alle, er det svenske projekt Snilleblixt, hvis navn måske bedst kan oversættes til at betyde "lynende gode ideer".

\section{Svenske børn får lov at prøve selv}

Snilleblixtbevægelsen blev startet i 1993 af Anders Rosén, far til tre og opfinder. Hans udgangspunkt var, at der var for få muligheder for at lære gennem selvskabte projekter i sine børns skole. Og samtidig havde han ofte oplevet, at børn havde bedre og mere kreative ideer end voksne, når det gjaldt arbejdet med at opfinde. (10).

Dét, der startede som en enkelt dag på en enkelt skole, har nu udviklet sig til at være noget i nærheden af en national bevægelse. Skoler over hele Sverige huser nu Snilleblixt-projekter for børn mellem 6 og 11 år. Alle projekterne er bygget op om samme skabelon.

Børnene udfordres først til at finde et konkret problem i deres egen hverdag. Det kan være hjemme, i skolen, i legen eller i samfundet som helhed. Næste led er at opfinde en ting, der løser problemet og til sidst selv at bygge tingen - som model eller en reel prototype af produktet. Det foregår på skolerne, men $\mathrm{i}$ tæt kontakt med forældre, anden familie, og institutioner og virksomheder $\mathrm{i}$ lokalsamfundet.

De færdige produktioner udstilles hvert år ved en messe, hvor børn og voksne fra hele Sverige deltager. (11).

Det har givet mange overraskende og kreative produkter. Børn har opfundet vantevarmere, der kan sættes på radiatorer, og udnytte varmen derfra. To piger har opfundet et nyt bogstav, der skal

\section{Det nye bogstav - et Snilleblixtproduk}


Kilde: Snilleblixtarnas njemmeside, 1999

erstatte bogstavkombinationerne $s \mathrm{j}, \mathrm{stj}$, sk, skj, sch og ch, som alle repræsenterer den samme lyd. Bogstavet hedder "ske" og ser ud som vist i figuren neden for. Der er opfundet en picnic-kurv med ben, der kan gå selv, fordi "gamle mennesker bliver for tratte til at bare en picnic-kurv", og en "mega-gynge", som mange børn kan bruge på én gang, "sả ingen behøver at vere uden for".

Det bedste produkt er dog børnenes udvikling gennem projektet. De bliver stolte og fulde af tiltro til egne evner. Historien går om Maria på 8 år, som stolt påpegede overfor sin lærer, at "Frøken, Frøken, jeg er faktisk en Snilleblixt - jeg kan tænke selv!"

Børnene bliver positivt bekræftet $\mathrm{i}$ at kreative forslag, nysgerrighed og nye ideer har værdi. Og børns skaber- og tankekraft bliver samtidig synliggjort $i$ de voksnes verden.

Ideen med Snilleblixtarna bygger på frivillighed og en total grænseløshed inden for den ramme projektet angiver: At opfinde noget, der løser et problem, man selv har defineret. Denne konstruktion stimulerer børnenes idérighed og kreativitet.

\section{Digital teknologi som udviklingsredskab}

En af de største udfordringer for voksne, som arbejder med børn i dag, er at finde en god måde 
at integrere computere og anden teknologi i børns hverdag.

Next Generation Forum er nået frem til fire grundlæggende principper for netop dette område. De tager udgangspunkt i en grundlæggende forståelse af børn som designere, og udvikling som et spørgsmål om at teste grænserne for ens egen formåen.

\section{Principperne er:}

- Det er ikke teknologien i sig selv, der kan have en positiv effekt på børns udvikling. Det er måden teknologien bruges på, der er afgørende.

- En diskussion af udviklings- og læringsmål kommer før valget af teknologi. Den underliggende tilgang til udvikling kommer før redskaberne.

- Brug de teknologiske værktøjer som fingermaling snarere end fjernsyn. Det betyder et teknologisk redskab, der er åbent og tillader mange og fleksible løsninger.

- Alle partnerne i børns udvikling - dvs. voksne i de mange miljøer børn færdes i - må arbejde på at få en forståelse af ikke bare brugen af de teknologiske værktøjer i sig selv, men af hvordan de bedst indgår i projekter for børn.

Det helt afgørende for brugen af de nye teknologier er hvilken software vi putter i dem. Computere er - endnu - som computere nu er - en kasse, en skærm, en mus, et tastatur. Men der er stor forskel på software. Hvor nogen på bedste vis opfordrer og udfordrer børn og deres skaberevne, kan andre have direkte modsatrettede effekter på børns udvikling.

En meget omtalt amerikansk unders $\emptyset$ gelse fra 1998 viste, at software $\mathrm{i}$ form af simulationsprogrammer og brede konstruktionsprogrammer til rådighed havde en positiv effekt på større børns læring og forståelse af matematik. Til gengæld var effekten af software der bestod af gentagne $\varnothing v e l-$ ser og prøver direkte modsat. (12).
Pointen med teknologi er den samme som med alle andre redskaber, der hjælper børn til at udvikle sig og forstå deres verden bedre. De skal opfordre børn til at udforske og til at være aktive. Det handler om at redskabet er designet sådan, at den, der bruger det, spørger sig selv "Hvad kan jeg gøre med det her leget $\varnothing \mathrm{j} /$ computerprogram etc?" Som modsætning er der lukkede redskaber med fă udnyttelsesmuligheder og måske en tendens til en rigtig/forkert måde at bruge det på. Den slags redskaber har en tendens til at lære brugeren at stille spørgsmålet: "Hvad kan det her leget $\varnothing \mathrm{j} / \mathrm{computer}$ program gøre for mig?"

MediaLab ved Massachusetts Institute of Technology har et forskningsprogram kaldet "Toys of Tomorrow" - morgendagens leget $\varnothing$ j. Det er her LEGO's programmerbare klodser, kendt som Mindstorms, blev udviklet. Kendetegnende for alle produkter, som projektet udvikler, er, at de tager eksisterende leget $\varnothing \mathbf{j}$ og giver dem egenskaber, der opfordrer til deltagelse og samarbejde, ved at tilføre digitale egenskaber. Et eksempel på dette er PlayPal, som tager den svært populære GameBoy, og gør den til en lille, bærbar programmeringsmaskine, som kan bruges til at lave programmer til de føromtalte elektroniske LEGOklodser. (13)

\section{Partnerskaber}

Vejen til det kreative samfund er belagt med partnerskaber mellem alle interessenter i børns liv. Deltagerne i disse partnerskaber må dele ansvaret for at udfolde børns fulde potentiale. Det er ikke kun forældrenes eller skolernes ansvar. Skal alle børn sikres de bedste udviklingsmuligheder, kræver det, at forældre, pædagoger, lærere, arbejdsgivere, forskere og politikere erkender et fælles ansvar for børns vilkår og begynder et aktivt samarbejde.

I tråd med det nye børnesyn er det blevet aktuelt, at børn inddrages som partnere $\mathrm{i}$ beslutninger, der handler om deres liv. Et - måske ekstremt eksempel på børn som ligeværdige partnere er the Blue Mountain School i Oregon, USA. Her er en 16-årig dreng formand for skolebestyrelsen, og skolens overordnede princip er at børnene suverænt bestemmer, hvad de vil beskæftige sig med. 
Til gengæld virker alle børn meget motiverede, og med en god forståelse af at læring og viden er nøglen til succes. (14).

Grundprincipperne for partnerskaber generelt handler dog om langt mere end at børn selv skal involveres. Partnerskaber drejer sig om at parterne deltager med base i fælles værdier og frivillighed - ikke i lovmæssige forpligtelser. Desuden skal partnerskaber afspejle den sociale og kulturelle kontekst, de er en del af.

At alle løfter sammen er et uomgængeligt krav for at skabe de bedste vilkår for børn i det kreative samfund. Og en af de helt tunge interessenter $\mathrm{i}$ børns liv er politikere, regering og offentlige myndigheder.

\section{Børn kommer tættere på centrum}

Politisk har børn i de senere år fået en bedre platform i det danske samfund. Der er gennem de seneste fem år taget politiske skridt, der nærmest har landvindings-st $\emptyset r r e l s e$, for at bedre børns vilkår, rettigheder og ikke mindst muligheder i samfundet.

Startskuddet til børn på den politiske arena i Danmark kom for efterhånden en del år siden. Med kvinders gang fra hjemmebane til arbejdsmarked opstod behovet for et sted at placere børnene. Det førte til det ekstremt finmaskede net af daginstitutioner, vi kender i dag.

Men først i de allerseneste år har børn nærmet sig kernen af den politiske arena, i en grad så man kan se det.

Fra 1998 og med en foreløbig kulmination i foråret 2000 har flere politiske udspil fra den siddende regering handlet om børn:

- Regeringen kom i sommeren 1998 med en Børnefamiliepolitisk redegørelse, som lagde vægt på at fremme et mere børnevenligt arbejdsmarked, bedre dagpasningstilbud, fleksibel børnepasningsorlov og en indsats overfor de svagest stillede børn, unge og børnefamilier. (15)
- Børnerådet blev pr. 1. juli 1998 gjort til en permanent institution, som tager stilling til lovforslags indvirken på børns vilkår og agerer vagthund i forhold til, om Danmark overholder FN's børnekonvention.

- Den nye Lov om social service, der trådte i kraft i sommeren 1998 indeholder en styrkelse af kravene til daginstitutionernes indhold i forhold til den gamle bistandslov.

- I sommeren 1999 får Danmark sin første børnekulturpolitiske redegørelse, som i overskrifter beskæftiger sig med Kulturråd for børn og børnekulturkoordinatorer, nye partnerskaber for børn og kultur, teater, musik og billedkunst for børn, børns adgang til kulturarven, børn og medier, børn skal beskyttes, samtalevenner, værdier og foreningsliv, børn og biblioteker, børn og fysiske rammer og mere fokus på børn i kulturlovene. (16)

- I forsommeren år 2000 har Undervisningsministeren udsendt en folder med titlen "Værdier i virkeligheden", som handler om de værdier børn møder i den danske folkeskole.

- Socialministeriet offentliggør samtidig sit børneflagsskibsprojekt med titlen "Børn og værdier". Målet er, ifølge pressematerialet, "...en bred debat om værdier og ansvar mellem de forskellige aktører i barnets liv, lokalt der hvor børnene færdes i deres hverdag".

Alle disse projekter har været med til at få børn og barndommen ind i den danske samfundsdebat. I takt med at udspillene tager til i antal, kan man spore en anden progression. Den Børnefamiliepolitiske redegørelse, var som sådan et tegn på at børn begyndte at få større politisk opmærksomhed, men viste også, at der stadig var lighedstegn mellem familiens og børns behov, og at et fokus på børn i høj grad handlede om arbejdsmarkedet og ikke om børn. De senere udspil fra Kultur- og Socialministeriet har derimod børn og deres verden som omdrejningspunkt. Det samme gælder i nogen grad Undervisningsministerens udspil.

Kulturministeriets B $\varnothing$ rnekulturpolitiske redegørelse har mange af de elementer med, som det 
kreative samfund fordrer. Et af de mest synlige initiativer er oprettelsen af et børnekulturråd i december 1999. Rådet har til opgave at sætte børnenes mulighed for at udfolde deres fulde potentiale forrest i børnkulturpolitikken, og får en bevilling på 18 mio. kroner årligt. Rådet har netop til opgave at uddele penge for at afprøve nye samarbejdsmodeller mellem kulturens og uddannelsesverdenens interessenter $\mathrm{i}$ børn liv. Der bliver $\mathrm{i}$ redeg $\varnothing$ relsen lagt vægt på, at folkebibliotekerne bevæger sig ind i den digitale æra og tilbyder børn adgang til multimedieværktøjer. Og redegørelsen slår også fast, at kulturpolitikken skal hjælpe børn til at udfordre deres fantasi, skabertrang og kropsforståelse, ligesom det ikke kun handler om kultur for børn, men også med og af børn.

Det eneste man kan være ked af $i$ forhold til de meget udmærkede udspil, der kommer fra regeringen i øjeblikket, er, at de stadig har tendens til at vægte en situation, hvor børn skal rustes og forberedes på deres liv som borgere. Mellem linierne kan man se, at hensigten også er at give børn alle de muligheder, de kan få. Men det er barnet som kommende samfundsborger og deltager i de danske institutionelle strukturer, som redegørelser, debatoplæg og projekter har som primært udgangspunkt. Ikke barnet og barnets uomgængelige ret til at udvikle hele sit potentiale. Ikke barnet som suveræn navigat $\varnothing \mathrm{r}$ i sit eget liv.

\section{Inspiration på vej}

Next Generation Forum blev grundlagt i 1998 og udgav i efteråret 1999 sin første rapport: Toward the Creative Society. En af rapportens centrale anbefalinger er at begynde udviklingen af et Map of Creativity - et værktøj, der kan give alle interessenter inspiration til at børn verden over får bedre vilkår for at udvikle deres kreative potentiale.

Første udgave af Map of Creativity bliver offentligt tilgængeligt i løbet af dette års efterår. Next Generation Forum arbejder i øjeblikket med at lokalisere og bearbejde projekter for børn, som har best-practice elementer i sig, i forhold til at udvikle børns kreativitet.

Resultatet bliver udover en sammenlignende analyse af projekterne, som udgives i rapportform, et web-baseret søgeværktøj med beskrivelser af de individuelle projekter.

Mere information om Next Generation Forum kan fås ved at lægge vejen forbi www.nextgenerationforum.org, hvorfra 1999-rapporten også kan downloades. Der kan ligeledes skrives til Next Generation Forum på info@nextgenerationforum.org.

\section{Noter}

1. Toward the Creative Society - Next. Generation Annual Report 1999, Denmark,1999.

2. Interview med teknoprofeten Kevin Kelly i Ugebrevet Mandag Morgen, nr. 10, 2000.

3. Prøv at forstå cirkler med et "aktivt essay" på denne del af MIT's MediaLab's hjemmeside: http://el..ww.media.mit.edu/groups/el/ projects/circles

4. Anthony Giddens, The Third Way, The Renewal of Democracy, Policy Press, Cambridge 1998.

5. Kompetencerådets Rapport 1999, Huset Mandag Morgen, November 1999.

6. HFN, 11. oktober 1999, National Post, 6. marts 1999, og James McNeal, forsker i børns . forbrug ved Texas A\&M University, i Time International, 2. august 1999.

7. Teen Research Unlimited, San Jose Mercury News, 12. april 1999.

8. Den nye barndom, Interview med Dion Sommer, Samvirke, December 1999.

9. Fra Kompetencerådets rapport 1998, Mandag Morgen Strategisk Forum, 1998.

10. Al tilgængelig information om Snilleblixtprojektet kan findes på http://bli.snilleblixt.nu

11. Årets internationale Snilleblixt-messe foregår i Mölndal d. 25. maj om formiddagen. Kontakt Jan.Gott@molndal.se for mere information

12. Technology Counts 98: The Link to Higher Scores, 1998.

13. På www.media.mit.edu/Projects/resnick.html finder du en indgang til Toys for Tomorrow.

14. Jyllandsposten, maj 1999.

15. Fra Velfærdssamfundets Børn til Børnenes Velfærdssamfund Mandag Morgen Strategisk Forum, august 1998.

16. Se mere på Kulturministeriets hjemmeside: www.kum.dk. 